\title{
Certain Aspects of the Management Accounting System for Small and Medium-Sized Enterprises
}

\author{
Oleg A. Diegtiar ${ }^{1, *}$, Oleksandr V. Bezuhlyi ${ }^{2}$, Yuriy O. Tararuyev ${ }^{3}$, Tetiana O. Suslova ${ }^{4}$, \\ Tetiana V. Romanchenko ${ }^{4}$
${ }^{1}$ Department of Management and Public Administration, O.M. Beketov National University of Urban Economy in Kharkiv, 61002, Kharkiv, Ukraine
${ }^{2}$ Department of Regional Development and Local Governance, Kharkiv Regional Institute of Public Administration, National Academy for Public Administration under the President of Ukraine, 61001, Kharkiv, Ukraine
${ }^{3}$ Department of Entrepreneurship and Business Administration, O.M. Beketov National University of Urban Economy in Kharkiv, 61002, Kharkiv, Ukraine
${ }^{4}$ Department of Marketing, Kyiv National University of Trade and Economics, 02156, Kyiv, Ukraine

Received March 23, 2021; Revised May 30, 2021; Accepted June 15, 2021

\section{Cite This Paper in the following Citation Styles}

(a): [1] Oleg A. Diegtiar, Oleksandr V. Bezuhlyi, Yuriy O. Tararuyev, Tetiana O. Suslova, Tetiana V. Romanchenko, "Certain Aspects of the Management Accounting System for Small and Medium-Sized Enterprises," Universal Journal of Accounting and Finance, Vol. 9, No. 3, pp. 469 - 476, 2021. DOI: 10.13189/ujaf.2021.090321.

(b): Oleg A. Diegtiar, Oleksandr V. Bezuhlyi, Yuriy O. Tararuyev, Tetiana O. Suslova, Tetiana V. Romanchenko (2021). Certain Aspects of the Management Accounting System for Small and Medium-Sized Enterprises. Universal Journal of Accounting and Finance, 9(3), 469 - 476. DOI: 10.13189/ujaf.2021.090321.

Copyright $\bigcirc 2021$ by authors, all rights reserved. Authors agree that this article remains permanently open access under the terms of the Creative Commons Attribution License 4.0 International License

\begin{abstract}
The importance of sustaining small and medium-sized enterprises (SMEs) around the world is increasing rapidly each year. In modern days many countries try to develop methods to preserve this type of companies given recent global crisis. SMEs in the Ukrainian economy account for $99.98 \%$ of the total business population. Relevance of this study consists in the significant role of the SMEs in the structure of national economy and their importance in development of the modern domestic economic systems. Objectives of the study are to determine prospects, shortcomings and features of establishing management accounting practices (MAPs) in SMEs. The problem of the study consists in fragmentation of the knowledge in the literature relating to management accounting practices in small and medium sized enterprises and problems of establishing them, due to restriction of resources and particularly wide gap between management accounting theory and practice compared to larger companies. Trends in the small and medium-sized enterprises in the structure of the national economy and their role in the development of the domestic economic system can be predicted on the basis of several reviewed cases. This confirms the relevance of the analysis of the management accounting system of economic entities in order to determine
\end{abstract}

financial reserves to ensure economic activity in a crisis. Automated parametric control systems have been developed and proposed for implementation as elements of management accounting in order to provide processes for planning, monitoring and controlling of operational processes, as well as provide information and analytical support for management decision-making as a result of this study.

Keywords Financial and Economic Support, Business Processes, Unstable External Environment, Marketing Events

\section{Introduction}

In the context of crisis events in the economy, associated with negative trends in the level of financial and economic support for business processes through quarantine, caused by the coronavirus epidemic, as one of the urgent global challenges for the world economy, an important aspect of management ensures the strategic path of development of the enterprise in an unstable external environment $[1 ; 2]$. Also, 
the high tax burden is a significant problem for the development of small and medium-sized enterprises in Ukraine, which especially significantly affected the development of business in the conditions of lower revenues and higher costs for marketing events, which is associated with the complication of consumer search processes in the conditions of transition to the "online" [3;4]. Therefore, in the context of crisis events and high financial risks, the establishing of a management accounting system for small and medium-sized enterprises is of particular relevance in order to ensure the effectiveness of the management functions of planning, organizing and controlling operational processes, as well as to provide a strategic vector for the development of economic entities in case of instability and the need for organizational transformations. The relevance of the question determined the theme of the article and the prospects for further research.

The theme of improving the efficiency of management accounting has always been of high relevance and attracted the attention of researchers, which is associated with the need to transform the management system in accordance with the requirements and changes of the external environment for the economic entity. So, management accounting processes were investigated in the work of scientists such as A. A. Kostyakova, who determines the strategic aspects of the implementation of the management accounting system [5]. Authors V. R. Shevchuk, V. S. Ponomarenko, I. O. Zolotarova, R. K. Butova and S. Ya. Babinska considered certain aspects of information and analytical support of management accounting processes of enterprises [6-8]. However, despite the authors' attention to the issue of building a management accounting system due to significant changes in the external environment, it is necessary to modernize approaches to establishing a management accounting system [9-11].

The purpose of the article is to find ways to increase the efficiency of management accounting in the context of new challenges and transformations of social development processes.

A number of objectives have been identified and are addressed to achieve this purpose, including the following:

- to identify the main tasks that the business environment poses to management accounting;

- to analyze the problematic aspects of the implementation of management accounting in the system of operational processes;

- to determine the role of management accounting in the system of ensuring the financial and economic activities of economic entities;

- to develop proposals to improve management accounting for small and medium-sized enterprises.

\section{Materials and Methods}

In the context of crisis events in the economy, global economic problems caused by quarantine measures and the decline in international economic cooperation, special attention should be paid to the issue of ensuring the effectiveness of management accounting as part of the functions of planning, organizing and monitoring the operational and strategic activities of economic entities [12-14]. Prior to the quarantine period in Ukraine, more than 1900 thousand economic entities belonging to small and medium-sized businesses were registered (Fig. 1).

Among them are 1.63 million of individual entrepreneurs and 343 thousand of legal entities. Small enterprises in the economy account for more than 95\% (83\% are microenterprises), almost $4.5 \%$ are medium-sized and only $0.1 \%$ are large. At the same time, it should be noted that the number of small enterprises continues to grow [16].

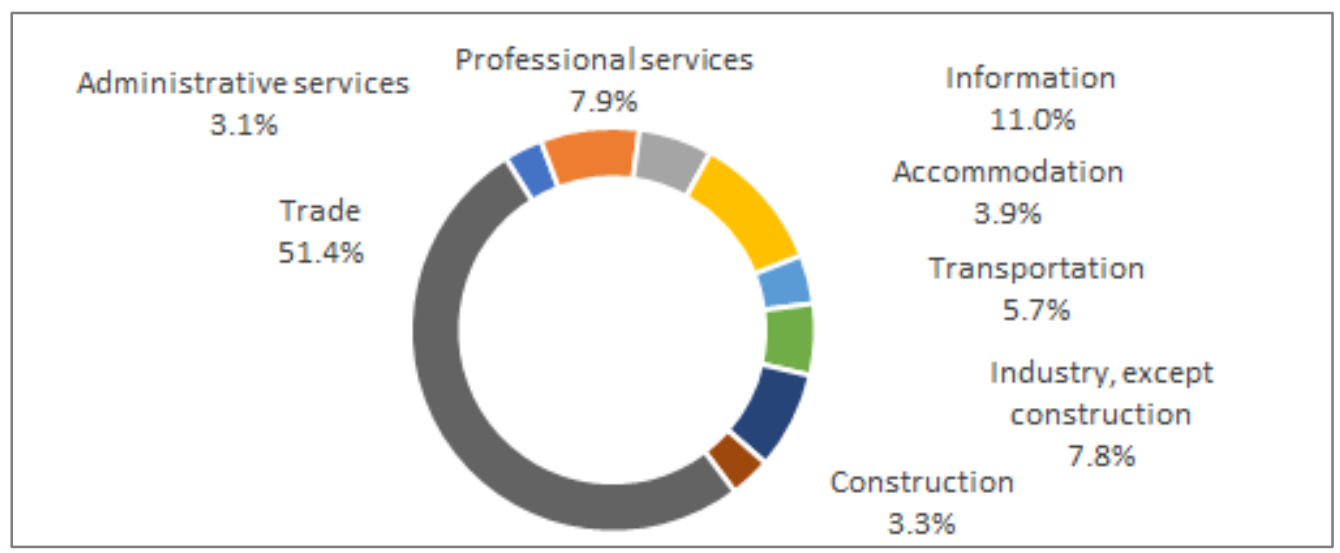

Figure 1. Sectoral distribution of SMEs in Ukraine, 2018 [15] 
Table 1. The main differences between Islamic banks and traditional

\begin{tabular}{|c|c|c|c|c|c|c|c|c|c|}
\hline & \multicolumn{3}{|c|}{ Small } & \multicolumn{3}{|c|}{ Medium } & \multicolumn{3}{c|}{ Total } \\
\cline { 2 - 10 } & No & Yes & Rank & No & Yes & Rank & No & Yes & Rank \\
\hline Costing system & 24 & 76 & 2 & 14 & 86 & 1 & 17 & 83 & 1 \\
\hline Budgeting system & 36 & 64 & 3 & 19 & 81 & 2 & 24 & 76 & 3 \\
\hline Performance measurement system & 22 & 78 & 1 & 20 & 80 & 3 & 21 & 79 & 2 \\
\hline Decision support system & 54 & 46 & 4 & 28 & 72 & 4 & 37 & 63 & 4 \\
\hline Strategic management accounting & 65 & 35 & 5 & 42 & 58 & 5 & 49 & 51 & 5 \\
\hline
\end{tabular}

In recent years, there has been a slight decrease in the number of medium-sized enterprises and a significant decrease in the number of large enterprises, which is associated with the violation of cooperation ties as a result of the ATO and the occupation of part of the territories of Luhansk and Donetsk regions (a powerful industrialized region with a high number of large enterprises), the annexation of the Crimean peninsula, global problems of economic development and the general crisis situation in the national economy [17-19]. Thus, it is possible to predict the trends towards an increase in small and medium-sized enterprises in the structure of the economy and an increase in their role in the development of the domestic economic system. In quarantine conditions, it is small and medium-sized enterprises that suffer the greatest losses, which is associated with the overwhelming sphere of their activities - the provision of services and limited financial opportunities for restructuring the system to "online ordering." It is in the context of a crisis that it is appropriate to carry out an analysis of the management accounting system of economic entities in order to determine financial reserves for ensuring economic development in a crisis [5].

In a general sense management accounting consists in the organization of a system of selection, evaluation of relevance, analysis of information, which is of value for ensuring management decisions and further control of compliance with planned and actual performance indicators [20]. Based of State Statistics Service of Ukraine data majority of SMEs used the five management accounting areas, which is shown in Table 1 .

The data show that budgeting system and performance measurement system are significantly higher than for decision support system and strategic management accounting, which indicates that the uptake of traditional MAPs is greater than the sophisticated management accounting practices. Data also indicate that a higher usage by medium companies is opposed to small companies. The most significant differences relate to the use of decision support system and strategic management accounting.

Management decision-making should be based on the following elements of the management accounting indicators [21;22]: analysis of indicators of financial and economic activity of previous years;

- projections of changes in the system of financial and economic activity of the economic entity;

- main performance indicators of competitors;

- the organizational component of the enterprise is presented in the form of quantitative indicators; analysis of possible changes and transformations of the external environment with determination of potential influence on the economic entity.

Thus, based on the analysis of management accounting elements, it is possible to define the following tasks that the management system poses to the accounting process $[7 ; 8]$ :

- supporting and quantifying the management decision-making system;

- creating a basis for the possibility of comparing similar indicators of different periods, individual divisions, branches, competitors, etc., gives an idea of the general tendency of trends in both internal and external environments for the economic entity;

- identifying financial income and expenditure, analysis of financial reserves;

- identifying the best opportunities to use financial reserves for business development;

analyzing unprofitable processes and their transformation in order to ensure financial efficiency;

- giving marketing policy to the economic entity with information about competitors, its analysis and development of its own marketing solutions in the triangle "own opportunities - rivalry with competitors - consumer interests";

creating conditions for the development of financial forecasts of the enterprise for the future.

The description of the main tasks of financial accounting makes it possible to determine its role in the financing and operating activities of economic entities [22]. However, small and medium-sized enterprises often face a number of challenges in implementing management accounting. Firstly, owners of small enterprises, in particular individual entrepreneurs, do not always understand the possibilities provided by management accounting in the enterprise, since in conditions of a small amount of 
financial revenues and limited operational processes, entrepreneurs establish a financial system manually [19; 20]. This situation affects negatively the further development of the enterprise, because the owner does not see potential opportunities for growth, paying great attention to unsystematic operational processes, there is no time to provide a strategic vector of development [23-25]. Such enterprises do not have the prospect of scaling and are in conditions of increased risks in crisis situations, without understanding their own financial reserves [26-29].

Secondly, the establishment of an effective management accounting system requires considerable time and financial injection. Business owners do not always understand the economic benefits of an established management accounting system [29; 30]. Also, if the management accounting system is set up incorrectly, the financial results may even be negative. Without understanding financial accounting processes and management decision-making elements, the owner can conclude that management accounting is ineffective. Thus, the effectiveness of management accounting can be minimized because its role has not been understood and the implemented approach is wrong [31].

\section{Results and Discussion}

Significant challenges in implementing management accounting system in small and medium-sized enterprises are:

- lack of financial capabilities and understanding of the effectiveness of the implementation of the management accounting system by business owners, as well as understanding the prospects of management accounting to provide opportunities for strategic development;

- economic instability, which affects significantly the processes of planning and control of actual and planned indicators of the financial and economic activity of the enterprise;

- the specificity of small and medium-sized enterprises indicates that they are unable to perform a number of functions that could ensure greater efficiency in their management accounting, in particular, influence pricing limits, demand or supply for their own products or services.

Solutions to these problems can be found in the works of several Ukrainian scientists, such as S.I Drobyazko, S.M. Denga, T.A. Gogol and others. They proposed to use integrated monistic system of linked financial and managerial accounting, in which analytical accounting and correspondence of accounts are organized by deriving information for accounting management from financial accounting data. They defined principles of preparation and the composition of managerial reporting of small business enterprises. They also mentioned necessity of financial and managerial accounting integration, with the addition of financial chart of accounts by accounting nomenclature and analytical accounts for the goals of the management accounts. Four-stage algorithm of managerial accounting implementation at a SMEs was developed by them [32-36].

A positive influence of small and medium-sized enterprises when creating a management accounting system is that if the system for organizing operational processes at the expense of smaller scales is simpler, it is more possible to have an interaction of management, marketing systems, operational processes. However, despite these advantages, most small and medium-sized enterprises refer to their management processes as current operational tasks without using management capacity to provide a strategic perspective. In view of the above, the authors consider it appropriate to provide the following recommendations on the establishment of a management accounting system for small and medium-sized enterprises, in particular [37]:

- prioritize the scaling of the own business, which is a key factor in the implementation of management accounting;

- identify the key indicators for analysis that have the greatest impact on the income and expenses of the enterprise;

- define performance parameters for key indicators;

- establish an effective financial planning system by analyzing all available resources, sources of income and objects of expenditure;

- offer an automated system for monitoring the parameters of indicators as actual results of the enterprise;

- create conditions for adjusting plans quickly according to changes in the external environment.

In the context of the national economic system, it is proposed to create the following accounting and control blocks: marketing, income, expenses, development funds, development tasks. According to the developed blocks, it is proposed to create relevant Google tables with common access by administrative and management personnel to them and the ability to make changes and adjustments to blocks that are within the area of competence of a particular employee. For example, an automated system for calculating the compliance of marketing plans and actual performance can be presented in the following Table 1. 
Table 1. Automated marketing activities calculation system

\begin{tabular}{|c|c|c|c|c|c|c|c|c|c|}
\hline & \multicolumn{9}{|c|}{ Number of applications } \\
\hline $\begin{array}{c}\text { Type of } \\
\text { advertising }\end{array}$ & 1 day & 2 day & 3 day & 4 day & 5 day & $\begin{array}{c}\text { Work Week } \\
\text { Total } \\
\end{array}$ & ... & $\begin{array}{l}\text { Total for } \\
\text { the month }\end{array}$ & $\begin{array}{l}\text { Total for } \\
\text { the year }\end{array}$ \\
\hline Contextual & & & & & & & & & \\
\hline Targeted & & & & & & & & & \\
\hline Banner & & & & & & & & & \\
\hline Others & & & & & & & & & \\
\hline
\end{tabular}

Table 2. Automated sales calculation system

\begin{tabular}{|c|c|c|c|c|c|c|c|c|c|}
\hline & \multicolumn{7}{|c|}{ Number of sales } \\
\hline Sales & $\mathbf{1}$ day & $\mathbf{2}$ day & $\mathbf{3}$ day & $\mathbf{4}$ day & $\mathbf{5}$ day & $\begin{array}{c}\text { Work Week } \\
\text { Total }\end{array}$ & $\cdots$ & $\begin{array}{c}\text { Total for } \\
\text { the month }\end{array}$ & $\begin{array}{c}\text { Total for } \\
\text { the year }\end{array}$ \\
\hline Product $\mathrm{A}$ & & & & & & & & & \\
\hline Product $\mathrm{B}$ & & & & & & & & & \\
\hline$\ldots$. & & & & & & & & & \\
\hline Product $\mathrm{N}$ & & & & & & & & & \\
\hline
\end{tabular}

These tables are entered by the Marketing and Advertising Manager daily. With MC Excel features, data for the week, month, and year are automatically summarized into the reporting. Thus, you can clearly see changes in the return on advertising, and quickly respond to the results of advertising campaigns when making adjustments. With a large assortment of goods, similar tables are formed for each individual type if different advertising campaigns work to sell different goods. An automated system for calculating the compliance of sales plans and actual sales volumes can be presented in Table 2 as follows.

Those responsible directly for sales enter daily operational information in these tables. The results for the week, month and year are calculated automatically. Comparing the results of the table data using statistical data analysis, the manager can identify:

- products that are popular, making it advisable to review the range of products;

- products that are very popular to increase their sales in high demand - it is advisable to increase advertising costs;

- advertising campaigns that work inefficiently and should be revised if sales of products decrease, if other business conditions remain unchanged $[38 ; 39]$.

To determine income from the sale of products, a similar table is filled in, for which the accountant is responsible, and the data are recorded not in the volumes of products sold (for example, pieces), but in monetary terms, which allows you to track the volumes of income of the enterprise and their main sources accurately. And also, "weak positions" require adjustment, because they bring less profit. In order to determine the possibilities of channeling financial resources to certain needs, it is necessary to determine operational costs and, based on their volume, form reserve funds and development funds. To determine expenses, it is proposed to create a table that will be automatically updated monthly with possible current adjustments in the form of Table 3 as follows.

Table 3. Expenses of the enterprise

\begin{tabular}{|c|l|c|l|l|l|}
\hline $\begin{array}{c}\text { Item of } \\
\text { expense }\end{array}$ & $\begin{array}{c}\mathbf{1} \\
\text { month }\end{array}$ & $\begin{array}{c}\mathbf{2} \\
\text { months }\end{array}$ & $\cdots$ & $\begin{array}{c}\mathbf{1 2} \\
\text { months }\end{array}$ & Year \\
\hline $\begin{array}{c}\text { Wages of } \\
\text { employees }\end{array}$ & & & & & \\
\hline $\begin{array}{c}\text { Taxes and } \\
\text { charges }\end{array}$ & & & & & \\
\hline Rent & & & & & \\
\hline Utilities & & & & & \\
\hline $\begin{array}{c}\text { Bonuses and } \\
\text { social } \\
\text { payments }\end{array}$ & & & & & \\
\hline Advertisement & & & & & \\
\hline $\begin{array}{c}\text { Maintenance } \\
\text { (cleaning, } \\
\text { organizational } \\
\text { equipment, } \\
\text { etc.) }\end{array}$ & & & & & \\
\hline $\begin{array}{c}\text { Other items of } \\
\text { expense }\end{array}$ & & & & & \\
\hline
\end{tabular}

By planning the expenses of an enterprise, what revenues need to be made can be determined in order to repay these expenses but not obtain damages. The amount of expenses by the number of working days per month was allocated. This amount is planned for daily sales receipts. If revenues come from sales according to the plan, it will automatically be clear that the enterprise can cover its own planned expenses. If there is a deviation in 
income per day, then from a managerial point of view, this information will indicate the need for operational management adjustments to plans: changing advertising campaigns, activating sales work, finding new forms of sales, providing additional services, viewing the range of products and the like. Thus, this management accounting system aims to ensure rapid monitoring of the implementation of plans, which is the main source of basic information for management decisions. According to ABCA 2016, lack of demand is the most important obstacle of SMEs developments. At the same time, according to the most recent analysis of the National Bank of Ukraine, the most important obstacle for businesses to increase their production output are high energy prices and high prices for raw materials. That is where the strong formalized lobby of small and medium business in form of associations might be important, as it enables the businesses to effectively advocate their interests in relations with monopolistic suppliers of raw materials and energy as well as lobby for other policy measures [40; 41]. Business associations also create networking opportunities that make it easier to create partnerships and enter new regional markets, thus increasing the demand for SMEs products and services.

\section{Conclusion}

As a result of the analysis, the relevance of management accounting system at small and medium-sized enterprises was determined. Despite the great attention of these enterprises to operational management, the importance and relevance of scaling the business and ensuring its strategic vector of development are provided. Small and medium-sized enterprises do not pay due attention to the processes of management accounting, which is attributed to the lack of experience of the owners of such enterprises in scaling a business and managing business processes.

However, the main advantages of management accounting at small and medium-sized enterprises are the ability to maintain primary accounting taking into account the processes of planning and forecasting performance indicators of the enterprise for the future. Before the implementation of management accounting, the main stage is the definition of business tasks before management accounting, because it affects the key parameters directly that will be considered as the main indicators of the accounting system at the enterprise (except for the key ones, which, for example, are income and expenses). The goals and objectives of the enterprise are basic indicators for understanding the capabilities of the management accounting system, its functional characteristics and performance parameters, which are set for its work.

Also, the strategic goals of the enterprise are also strategic goals for direct management accounting. If an enterprise is not ready to implement a management accounting system, the first stage of implementation should be to analyze the problematic aspects of the implementation of management accounting in the system of operational processes, determine its role in management decision-making. Understanding the goals and objectives of management accounting, it is possible to build your own accounting system, created by analogy with the template proposed in the article. The template is aimed at structuring financial flows by constantly monitoring financial processes using primary accounting, statistical data and algorithms for their analysis. The main task of management accounting is not just a statement of the results of the enterprise and the maintenance of statistics. it is necessary to provide an analytical analysis of the results of financial activities with an understanding of the reasons for the occurrence of certain business processes. this information can be used in forecasting, planning and making management decisions in small and medium-sized enterprises. Carrying out proper cost analysis for an action plan in the future would create financial certainty in the implementation period and provide for flexibility throughout the policy cycle in terms of funds allocation according to the set strategic priorities. The authors consider it appropriate to provide the following recommendations on the establishment of a management accounting SMEs, in particular, introduce a correlation principle, decrease the frequency of tax and commercial reporting intensify auditing duty, establish a working group for consulting and coordination with the relevant industry bodies.

\section{REFERENCES}

[1] E. V. Dudukalov, M. Imtiaz Subhani, D. Ushakov. Cross docking as a factor of distribution efficiencies improving in conditions of governance digitalization, IOP Conference Series: Materials Science and Engineering, Vol. 918, No. 1, $012188,2020$.

[2] J. S. Tsertseil, V. V. Kookueva, K. V. Ordov. Regional competitiveness within the cluster's territory: Case of the Volga Federal District's chemical industry, Progress in Economics Research, Vol. 37, 169-184, 2017.

[3] S. V. Laptev, F. V. Filina, D. V. Timohin. Competitiveness management of Russian innovation entrepreneurship, Studies in Systems, Decision and Control, Vol. 282, 325-331, 2020.

[4] N. E. Bondarenko, T. G. Bondarenko, L. V. Goryainova, T. P. Maksimova, O. A. Zhdanova. Development financing of the subjects of Russian agro-industrial complex, International Journal of Mechanical Engineering and Technology, Vol. 9, No. 8, 1187-1197, 2018.

[5] A. A. Kostyakova. Strategic management accounting: essence and concept, Accounting, Analysis and Audit, Vol. 39, No. 2, 99-102, 2019. 
[6] V. R. Shevchuk. Strategic management accounting as an information basis for strategic management of the enterprise, Bulletin of the National University "Lviv Polytechnic", Management and Entrepreneurship in Ukraine: Stages of Formation and Problems of Development, Vol. 797, 417-422, 2014.

[7] V. S. Ponomarenko, I. O. Zolotarova, R. K. Butova. Information Systems in Economics, KhNEU Publishing House, Kharkiv, 2011.

[8] S. Ya. Babinska. The concept of information support of an innovative project and stages of its implementation, Scientific Journal Business Inform, Vol. 1, 61-66, 2017.

[9] Z. M. Orynkanova, R. A. Baizholova, A. Z. Zeinullina. Improving the energy efficiency of Kazakhstan's economy, Journal of Environmental Management and Tourism, Vol. 11, No. 1, 44-53, 2020.

[10] Z. H. Shadova, P. A., Gurianov, S. N. Fedorova, A. V. Zemlyakova, O. V. Grishchenko. The structure of the share capital and the interests of the majority shareholder, International Journal of Economics and Financial Issues, Vol. 6, No. 1S, 211-219, 2016.

[11] P. Gurianov. Formation of pollutant emissions trading optimum model at the international market, Metallurgical and Mining Industry, Vol. 7, No. 8, 94-99, 2015.

[12] P. A. Gurianov. Small business in Russian Federation: State, potential threads, barriers and medium-term development perspectives, World Applied Sciences Journal, Vol. 30, No. 9, 1166-1169, 2014

[13] S. Zhang, T. N. Sakulyeva, E. A. Pitukhin, S. M. Doguchaeva. Neuro-fuzzy and soft computing - a computational approach to learning and artificial intelligence, International Review of Automatic Control, Vol. 13, No. 4, 191-199, 2020.

[14] A. A. Kartskhiya, S. A. Tyrtychnyy, M. G. Smirnov, M. G. Dolgikh, L. A. Khmelnitskiy. Digital technologies in supply chain management for production and digital economy development, International Journal of Supply Chain Management, Vol. 9, No. 3, 912-918, 2020.

[15] State Statistics Service of Ukraine, 2020, Online available from https://ukrstat.org/about.html

[16] Official site of the State Statistics Service of Ukraine. Statistics, 2020, Online available from http://www.ukrstat.gov.ua/

[17] D. Topchiy, A. Tokarskiy. Formation of hierarchies in the system of organization of state construction supervision in case of reorientation of urban areas, Communications in Computer and Information Science, Vol. 1046, 134-143, 2019.

[18] A. A. Lapidus, N. Yves. Integrated quality index of organizational and technological solutions for implementation of Burundian capital master plan, Materials Science Forum, Vol. 931, 1295-1300, 2018.

[19] N. Ezdina. Humanity and environment co-influence in the shadow of technological convergence, E3S Web of Conferences, Vol. 21, 04015, 2017.

[20] Management Accounting at the Enterprise, 2018, Online available

from https://inteltech.com.ua/uk/blogs/upravlinskyy-oblik-na-pi dpryyemstvi-vedennya-upravlinskogo-obliku-v-1c.

[21] V. M. Kostyuchenko, A. M. Malynovska, A. V. Mamonova. Genesis of management accounting in the conditions of permanent changes, Economy and Society, Vol. 8, 933-942, 2018.

[22] A. Heinicke. Performance measurement systems in small and medium-sized enterprises and family firms: a systematic literature review, Journal of Management Control, Vol. 28, No. 4, 457-502, 2018.

[23] D. Topchiy, A. Tokarskiy. Designing of structural and functional organizational systems, formed during the re-profiling of industrial facilities, IOP Conference Series: Materials Science and Engineering, Vol. 365, No. 6, $062005,2018$.

[24] A. Lapidus, T. Dmitry. Formation of methods for assessing the effectiveness of industrial areas' renovation projects, IOP Conference Series: Materials Science and Engineering, Vol. 471, No. 2, 022034, 2019.

[25] A. A. Zhigir. Calculation of the economic effect of environmental measures, IOP Conference Series: Earth and Environmental Science, Vol. 421, No. 7, 072002, 2020.

[26] G. Nigri, M. D. Baldo. Sustainability reporting and performance measurement systems: How do small- and medium- sized benefit corporations manage integration? Sustainability (Switzerland), Vol. 10, No. 12, article number 4499, 2018.

[27] H. M. Armitage, D. Lane, A. Webb. Budget Development and Use in Small- and Medium-Sized Enterprises: A Field Investigation, Accounting Perspectives, Vol. 19, No. 3, 205-240, 2020.

[28] T. Łuczka, J. Małecka. Knowledge management in micro and small enterprises in Poland, Proceedings of the European Conference on Knowledge Management, Vol. 1, 476-484, 2018

[29] E. Pedroso, C. F. Gomes. The effectiveness of management accounting systems in SMEs: a multidimensional measurement approach, Journal of Applied Accounting Research, Vol. 21, No. 3, 497-515, 2020.

[30] I. Bashynska, I. Lytovchenko, D. Kharenko. Sales tunnels in messengers as new technologies for effective internet-marketing in tourism and hospitality, International Journal of Innovative Technology and Exploring Engineering, Vol. 8, No. 12, 594-598, 2019.

[31] R. A. Abramov, M. S. Sokolov. Features of corruption in the educational sphere in the context of globalization of educational space, Journal of Legal, Ethical and Regulatory Issues, Vol. 20, Special Issue 1, 1-10, 2017.

[32] L. Johnstone. A systematic analysis of environmental management systems in SMEs: Possible research directions from a management accounting and control stance, Journal of Cleaner Production, Vol. 244, article number 118802, 2020.

[33] S. I. Drobyazko, Organization of management accounting in small business enterprises, Finances. Law: Informational and Analytical Magazine, Vol 2, 68-70, 2013.

[34] T. A. Gogol. Accounting and analytical support in the 
management of small enterprises, Publisher Lozovyy V.M., Chernihiv, 384.

[35] S. M. Denga, Organization of management accounting in the conditions of computerization, 2007, Online available from https://goo.gl/zdXDAw

[36] M. Hosoda. Management control systems and corporate social responsibility: perspectives from a Japanese small company, Corporate Governance (Bingley), Vol. 18, No. 1, 68-80, 2018.

[37] L. Corazza. The standardization of down-Streamed Small Business Social Responsibility (SBSR): SMEs and their sustainability reporting practices, Information Resources Management Journal, Vol. 30, No. 4, 39-52, 2017.

[38] A. Ströbele, P. Wentges. The role of organizational social capital in the design of management control systems, Journal of Management Accounting Research, Vol. 30, No.
$2,187-205,2018$.

[39] E. Truant, L. Broccardo, F. Culasso. Management control practices and benefits: Evidence from Italian family and non-family firms, World Review of Entrepreneurship, Management and Sustainable Development, Vol. 13, No. 5-6, 612-634, 2017.

[40] H. Kuzmenko, K. Yahelska, O. Artyukh, I. Babich, N. Volenshchuk, L. Sulimenko. Improved methodology of accounting and audit of payments to employees in Ukraine, Universal Journal of Accounting and Finance, Vol. 9, No. 1, 44-53, 2021. DOI: 10.13189/ujaf.2021.090105

[41] R. Rachmawati, Widowati. Research of the impact of financial dimensions and entrepreneurial capacity on business performance in small and medium enterprises in central Java, Universal Journal of Accounting and Finance, Vol. 9, No. 1, 122-129, 2021. DOI: 10.13189/ujaf.2021.090113 